\title{
Free radical scavenging ability of Ximenia americana L. stem bark and leaf extracts
}

\author{
Valdiléia Teixeira Uchôa ${ }^{1,4,5}$, Cleyton Marcos Melo Sousa ${ }^{2,5}$, Adonias Almeida Carvalho ${ }^{3,5}$, Antônio Euzébio Goulard \\ Sant'Ana ${ }^{4}$, Mariana Helena Chaves ${ }^{5 *}$ \\ ${ }^{1}$ Chemistry Department, University State Piauí, Teresina - Piauí, Brazil. ${ }^{2}$ Chemistry Department, Institute Federal of Pernambuco, Pesqueira - \\ Pernambuco, Brazil. ${ }^{3}$ Chemistry Department, Institute Federal of Maranhão, Codó - Maranhão, Brazil. ${ }^{4}$ Institute of Chemistry and Biotechnology, \\ University Federal of Alagoas, Maceió - Alagoas, Brazil. ${ }^{5}$ Chemistry Department, University Federal of Piauí, Teresina - Piauí, Brazil.
}

\section{ARTICLE INFO \\ Article history: \\ Received on: 08/10/2015 \\ Revised on: 15/11/2015 \\ Accepted on: 11/12/2015 \\ Available online: $27 / 02 / 2016$}

Key words:

Ximenia americana,

antioxidant, DPPH

epicatechin, Quercetin.

\begin{abstract}
Phytochemical investigation of the ethanol extract of stem bark and leaves of Ximenia americana L. revealed the presence of epicatechin and quercetin, respectively. This is the first report of the occurrence of epicatechin in this genus. The extracts, fractions and isolated compounds of $X$. americana were subjected to an in vitro antioxidant activity assay by the DPPH method (2,2-diphenyl-1-picrylhydrazyl). The $\mathrm{EC}_{50}$ values were calculated and the results indicate that the ethyl acetate fractions of the stem bark and leaves have high antioxidant activity and a high content of total phenols. The high antioxidant activity of these fractions is justified by the presence of epicatechin and quercetin.
\end{abstract}

\section{INTRODUCTION}

Irreversible damage to proteins, carbohydrates, lipids and nucleic acids are some of the factors responsible for the development of numerous degenerative diseases, such as atherosclerosis, Parkinson's disease, Alzheimer's disease, cardiovascular diseases, cancer and diabetes (Lodyato et al., 2004). Fruits and vegetables are important in human diet because they contain antioxidative components that protect against free radicals and that have been associated with reduced risk of these degenerative diseases (Zhang and Hamauzu, 2004, Sharma, et al., 2015). The compounds responsible for antioxidant activity are of endogenous origin, such as enzymes and proteins, and of exogenous origin, such as low-molecular-mass substances like vitamins, carotenoids, flavonoids, anthocyanins and other phenolic compounds commonly present in plants (Argolo et al., 2004; Zhang and Hamauzu, 2004; Yin et al., 2015). Several methods have been developed to determine the antioxidant capacity of pure substances and extracts of plants. One of the most reliable methods involves measuring the sequestration of

\footnotetext{
* Corresponding Author

Chemistry Department, University Federal of Piauí, Campus

Universitário Ministro Petrônio Portella, Bairro Ininga, Teresina-PI.

Tel: +55-86-32371584,Email: mariana@ufpi.edu.br
}

free radical 2,2-diphenyl-1-picrylhydrazyl (DPPH), or other color radicals (Roginsky and Lissi, 2005, Fu et al., 2010). DPPH is a stable free radical at room temperature, with a typical violet color in methanol solution, and its use is indicated as a reagent for testing the radical scavenging activity of small molecules (Roginsky and Lissi, 2005, Fu et al., 2010). In this type of assay, scavenging of the DPPH• radical is verified by monitoring the decrease of absorbance at $516 \mathrm{~nm}$ resulting from the antioxidant activity (AH) (DPPH• + $\mathrm{AH} \rightarrow \mathrm{DPPH}-\mathrm{H}+\mathrm{A} \bullet$ ) (Argolo et al., 2004; Sánchez-Moreno et al, 1998). Ximenia americana is a thorny bush belonging to the family Olacaceae, found in tropical regions of America and Africa (Pott and Pott, 1994). In Brazil it is known by several popular names: ameixa-da-baia, ameixa-da-terra, ameixa-de-espinho and sândalo-do-brasil (Braga, 1960). All the parts of this plant are used in folk medicine (James et al., 2008, Braga, 1960).

The roots have antiseptic properties and are used in the treatment of fever, jaundice and headaches. The leaves have a laxative action and are indicated in the treatment of measles (Omer and Elnima, 2003). The powdered stem is recommended for healing ulcers, as a depurative, as a menstrual regulator and for gastric upsets. The infusion of its flowers serves to reduce bloody diarrhea (Braga, 1960). 
This plant is also active against rheumatism, cancer and many infections (Mevy et al., 2006). A pharmacological study of $X$. americana indicates that this species presents anticancer and antineoplastic (Voss, et al, 2006), antimicrobial (Geyid et al., 2005, Omer and Elimina, 2003), antibacterial (Koné et al., 2004, Kawo et al., 2011, Da Silva et al., 2015), activity antipyretic (Soro et al., 2009), radical scavenging (Maikai et al., 2010, Le et al., 2012) and pesticidal activity (Fatope et al., 2000).

In this work, the DPPH radical scavenging activity was evaluated and the total phenolic content of ethanol extracts $(\mathrm{EtOH})$ of the stem bark and leaves of $X$. americana was determined, as well as the fractions obtained from the liquid-liquid partitioning of the extracts. In addition, biomonitored fractionation of the ethyl acetate fraction of the stem bark and leaves was performed, resulting in the isolation of the flavonoids, epicatechin and quercetin as active compounds. This is the first report on the isolation and characterization of epicatechin in this specie, as well of the DPPH radical scavenging activity and total phenolic content of ethanol extract $(\mathrm{EtOH})$ and fractions of the stem bark of $X$. americana.

\section{MATERIALS AND METHODS}

\section{General experimental procedures}

All the solvents and reagents used in the preparation of the extracts and fractionations were of analytical grade (PA) supplied by Vetec (gallic acid), Merck (Sephadex LH-20, $\mathrm{SiO}_{2}, 70$ - 230 mesh; Folin-Ciocalteu), Aldrich Co (DPPH), PVP Sociedade Anônima, Parnaíba-Piauí (rutin), Synth and Ecibra. ${ }^{1} \mathrm{H}$ and ${ }^{13} \mathrm{C}$ NMR spectra were recorded on a Bruker Avance DRX-500 spectrometer at 500 and $125 \mathrm{MHz}$, respectively, using $\mathrm{CD}_{3} \mathrm{OD}$ as solvent. The absorption measurements were determined by an UVVis spectrophotometer PerkinElmer, Lambda 25.

\section{Vegetable material}

The stem and leaves of the species Ximenia americana L. were collected in April 2010 in the municipality of Campo Maior, state of Piauí, Brazil, and identified by Dr. Maria Edilene Alencar. An exsiccatum was deposited in the Grasiela Barroso herbarium at the Federal University of Piauí under number TEPB 14407.

\section{Extraction and fractionation of the plant}

The collected stems and leaves of $X$. americana were separated and dried at room temperature $\left(26{ }^{\circ} \mathrm{C} \pm 1\right)$ away from light. Dried and powdered, stem bark $(3.3 \mathrm{~kg})$, stem wood $(2.5 \mathrm{~kg})$ and leaves $(1.5 \mathrm{~kg})$ were extracted three consecutive times with $95 \%$ ethanol in a stainless steel extractor at a temperature of 26 ${ }^{\circ} \mathrm{C} \pm 1$.

Ethanol extracts of the stem bark (620 g, 18\%), stem wood $(250 \mathrm{~g}, 10 \%)$ and leaves $(230 \mathrm{~g}, 15 \%)$ were obtained after concentration in a low-pressure rotary evaporator and elimination of the residual humidity by lyophilization.

The ethanol extracts of stem bark $(500 \mathrm{~g})$ and leaves $(210$ g) were suspended separately in a $\mathrm{MeOH} / \mathrm{H}_{2} \mathrm{O}$ mixture (2:3) and subjected successively to the liquid-liquid partitioning process with $\mathrm{C}_{6} \mathrm{H}_{14}(3 \times 700 \mathrm{ml}), \mathrm{CHCl}_{3}(3 \times 700 \mathrm{ml})$ and EtOAc $(3 \times 700$ $\mathrm{ml}$ ). After removal of the solvent at low pressure in the rotary evaporator and lyophilization of the hydromethanol fraction, four fractions were obtained of the ethanol extract of the leaves: in hexane $(15.5 \mathrm{~g} ; 7.4 \%)$, in chloroform $(7.5 \mathrm{~g} ; 3.2 \%)$, in ethyl acetate $(80.9 \mathrm{~g} ; 38.5 \%)$ and hydromethanol $(101 \mathrm{~g}, 48 \%)$, and four fractions of the ethanol extract of the stem bark: in hexane $(10.75$ $\mathrm{g} ; 1.7 \%)$, in chloroform $(7.2 \mathrm{~g} ; 1.2 \%)$, in ethyl acetate $(220 \mathrm{~g}$; $45 \%)$ and hydromethanol $(240.4 \mathrm{~g} ; 48 \%)$. The raw extracts in ethanol and fractions resulting from partitioning were subjected to in vitro antioxidant activity assays.

\section{Phytochemical isolation}

The ethyl acetate fraction (200.0 g) of stem bark was subjected to chromatography in a deactivated silica gel column with $10 \%$ water $(800 \mathrm{~g})$, using ethyl acetate and methanol as eluant solvents. Three subfractions were obtained from the passage of $1000 \mathrm{ml}$ of each solvent: C1- EtOAc (46.54 g, 23.2\%), C2- EtOAc (29.11 g, 14.5\%) and C3-MeOH (76.66 g, 38\%).

An aliquot of subfraction $\mathrm{C} 1-$ EtOAc (40.0 g) was subjected to silica gel column chromatography (300 g). Seven fractions were collected with a volume of $500 \mathrm{~mL}$ each, using $\mathrm{CHCl}_{3}, \mathrm{MeOH}$ and mixtures of these as eluants.

After removal of the solvent, the $\mathrm{CHCl}_{3}: \mathrm{MeOH} 20 \%$ (17 g, 42.5\%) fraction yielded a wine-colored amorphous solid. Part of this material ( $3.5 \mathrm{~g}$ ) was subjected to crystallization in ethyl ether and ethyl acetate $1: 1$, three consecutive times, yielding compound 1 ( $1 \mathrm{~g}, 28 \%)$.

The EtOAc $(70 \mathrm{~g})$ fraction of the leaves was subjected to activated charcoal filtration in a Buchner funnel. Six subfractions were obtained from the passage of $1000 \mathrm{ml}$ of each of the following solvents, which, after being eliminated, yielded the following fractions: $\mathrm{H}_{2} \mathrm{O}(40 \mathrm{~g}, 57 \%), \mathrm{EtOH} / \mathrm{H}_{2} \mathrm{O} 1: 1(10 \mathrm{~g}, 14 \%)$, EtOH (7 g, 10\%), EtOAc (5 g, 7\%), $\mathrm{CHCl}_{3}(2 \mathrm{~g}, 3 \%)$ and $\mathrm{C}_{6} \mathrm{H}_{14}(2$ $\mathrm{g}, 3 \%)$.

The EtOAc (3 g) fraction was subjected to silica gel column chromatography $(30 \mathrm{~g})$ and eluted with a mixture of $\mathrm{CHCl}_{3}$ and $\mathrm{MeOH}$. Thirty-five fractions of $30 \mathrm{~mL}$ each were collected, analyzed by silica-gel thin-layer chromatography (CCD), and grouped. The 17-24 (1.5 g, 50\%) fraction was purified in a Sephadex LH-20 column using $\mathrm{MeOH}$ as solvent. This procedure was repeated twice and led to the isolation of compound $2(1 \mathrm{~g}, 66.6 \%)$.

(-) epicatechin (1): brown amorphous solid, MP $239{ }^{\circ} \mathrm{C}$ (EtOH). $[\alpha]_{D}^{29}-45(\mathrm{c}=1.0 \mathrm{MeOH}) . \mathrm{IR} \mathrm{cm}^{-1}: 3502,3412 \mathrm{~cm}^{-1}(\mathrm{O}-$ H). ${ }^{1} \mathrm{H}$ RMN (500 MHz, $\left.\mathrm{CD}_{3} \mathrm{OD}\right): \delta 4.83$ (d, $\left.J=7.5 \mathrm{~Hz}, \mathrm{H}-2\right)$, 4.19 (br s, H-3), 2.88 (dd, $J=4.5,16.7 \mathrm{~Hz}, \mathrm{H}-4_{\text {syn }}$ ), 2.76 (dd, $J=$ 2.7, $\left.16.7 \mathrm{~Hz}, \mathrm{H}-4_{\text {anti }}\right), 5.97$ (d, $\left.J=2.3 \mathrm{~Hz} \mathrm{H}-6\right), 5.94$ (d, $J=2.3 \mathrm{~Hz}$ H-8), 7.00 (d, $J=1.7 \mathrm{~Hz} \mathrm{H}-2$ '), 6.78 (d, $J=8.2 \mathrm{~Hz} \mathrm{H}-5$ '), 6.82 (dd, $J=1.7,8.2 \mathrm{~Hz} \mathrm{H}-6$ '). ${ }^{13} \mathrm{C}-\mathrm{NMR}\left(125 \mathrm{MHz}, \mathrm{CD}_{3} \mathrm{OD}\right): \delta 80$ (C2), 67.6 (C-3), 29.8 (C-4), 158.1 (C-5), 96.5 (C-6), 157.7(C-7), 96 (C-8), 157.5 (C-9), 100 (C-10), 132.4 (C-1'), 115.4 (C-2'), 145.8 
(C-3'), 146 (C-4'), 116 (C-5'), 119.5 (C-6'). The data were equal to those of literature data (Lopes et al., 2012, Wei et al., 2013).

Quercetin (2): yellow solid, MP $312{ }^{\circ} \mathrm{C}(\mathrm{EtOH}) . \mathrm{IR} \mathrm{cm}^{-1}$ : $3420 \mathrm{~cm}^{-1}(\mathrm{O}-\mathrm{H}), 1725 \mathrm{~cm}^{-1}(\mathrm{C}=\mathrm{O}) .{ }^{1} \mathrm{H}$ RMN (500 MHz, CD $\left.{ }_{3} \mathrm{OD}\right)$ : $\delta 6.20(\mathrm{~d}, J=2.0 \mathrm{~Hz}, \mathrm{H}-6), 6.39$ (d, $J=2.0 \mathrm{~Hz}, \mathrm{H}-8), 7.74$ (d, $J=$ $2.2 \mathrm{~Hz}, \mathrm{H}-2$ '), 6.89 (d, $J=8.5 \mathrm{~Hz}, \mathrm{H}-5$ '), 7.65 (dd, $J=8.5,2.2 \mathrm{~Hz}$, H-6'). ${ }^{13} \mathrm{C}-\mathrm{NMR}\left(125 \mathrm{MHz}, \mathrm{CD}_{3} \mathrm{OD}\right): \delta 147.8$ (C-2), 137 (C-3), 177 (C-4), 162.1 (C-5), 99.2 (C-6), 165.2 (C-7), 94.4 (C-8), 158 (C-9), 104.4 (C-10), 124 (C-1'), 115.8 (C-2'), 146 (C-3'), 148.5 (C$\left.4^{\prime}\right), 116.1$ (C-5'), $121.6\left(\mathrm{C}-6^{\prime}\right)$. The data were equal to those of literature data (Wei et al., 2013).

\section{Determination of antioxidant activity and dosage of total phenolics}

The antioxidant activity was evaluated by 2,2-diphenyl1-picrylhydrazyl (DPPH) free radical consumption, and the quantification of phenolic compounds determined by FolinCiocalteu method and expressed in gallic acid equivalent (GAE) according to Sousa et al., (2007), Costa et al., (2010) and Ferreira et al., (2014).

\section{Statistical analysis}

The results presented in this study correspond to the mean value of three repetitions $(n=3) \pm$ standard deviation of the mean. The results of antioxidant activity that presented a probability of occurrence of the null hypothesis of less than $5 \%(P$ $<0,05)$, applying ANOVA followed by Tukey's multiple comparison test, were considered statistically different. All the analyses were performed using Microcal Origin 8.0 software.

\section{RESULTS AND DISCUSSION}

\section{Structural identification of the isolated substances}

Compound 1 and 2 (Figure 1) was identified to be (-) epicatequin e quercetin, respectively for comparison of the spectroscopic data (IR and the one- and two-dimensional NMR) with those reported in the literature Lopes et al., 2012, Wei et al., 2013.

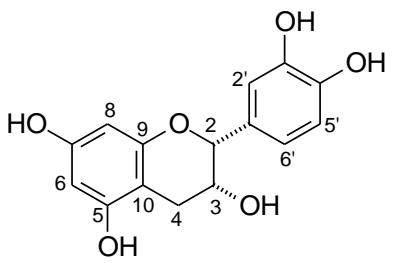

1

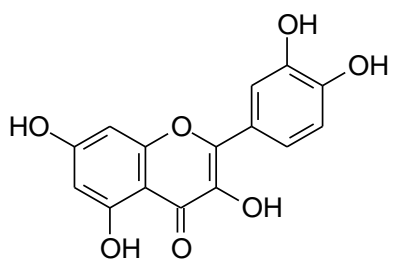

2
Fig. 1: Compounds isolated from the EtOH extract of X. americana.

\section{In vitro radical scavenging activity}

Evaluation of the antioxidant activity of extracts and molecules in assays with the DPPH radical is a widely used method because it is easy to perform and less time-consuming than other methods. The reaction can be observed visually by thin-layer chromatography (qualitative assay) and its intensity can be evaluated by chromometric or spectrophotometric assays (Sánchez-Moreno et al., 1998; Soler-Rivas et al., 2000). The DPPH radical is sequestered by antioxidants through the donation of hydrogen to form the stable molecule of DPPH in the reduced form (Argolo et al., 2004).

Figure 2 shows the radical scavenging activity, expressed in percent of inhibition (PI), exhibited by the ethanol extracts of the stem bark, stem wood and leaves of $X$. americana, in the concentrations of 250, 200, 150, 100, 50 and $25 \mu \mathrm{g} / \mathrm{ml}$. Based on these data, it is evident that the ethanol extracts of the leaves, stem bark and wood of $X$. americana contain substances that act as hydrogen donors to the DPPH radical, although they show a differentiated action.

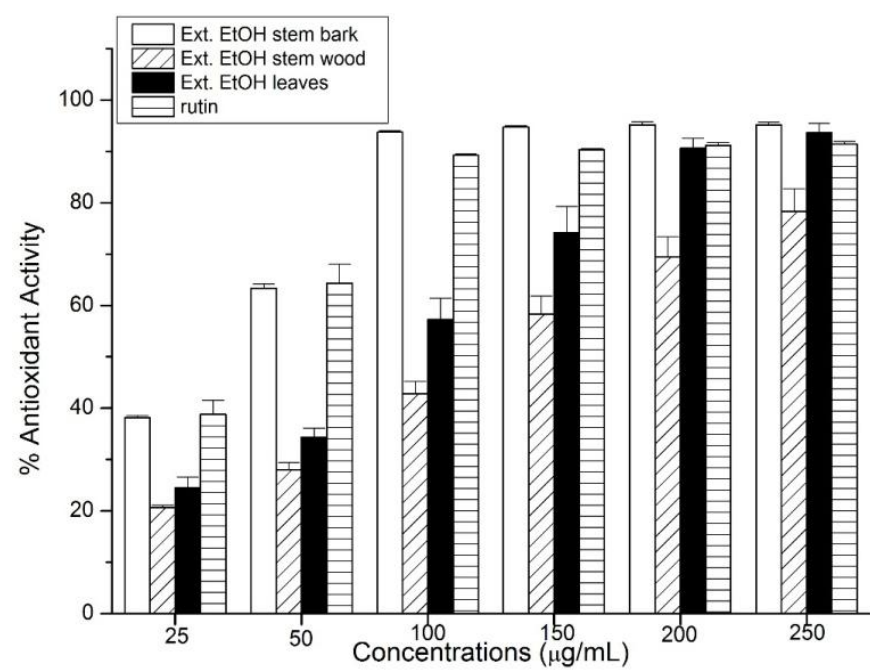

Fig. 2: Antioxidant activity of the EtOH extracts of Ximenia americana versus rutin (control group).

The ethanol extract of the stem bark showed the highest radical scavenging activity in all the concentrations, and was the most effective in sequestering the DPPH radical, reaching a percent of inhibition of more than $90 \%$ at the concentration of 100 $\mu \mathrm{g} / \mathrm{ml}$. The ethanol extract of the stem wood showed a PI = $78.29 \%$ at the concentration of $250 \mu \mathrm{g} / \mathrm{ml}$, displaying a lesser capacity to sequester the DPPH radical.

Taking into consideration the statistical analysis of the data on radical scavenging activity at all the tested concentrations $(25,50,100,150,200$ and $250 \mu \mathrm{g} / \mathrm{ml})$, and applying ANOVA and Tukey's test, it was found that the ethanol extract of stem bark showed a significant difference $(\mathrm{P}<0.05)$ in relation to the ethanol extracts of stem wood and leaves, but did not show a significant difference $(P<0.05)$, as a source of free radical scavenging substances, in relation to the positive control rutin.

The leaf extract showed a higher radical scavenging activity than the stem wood extract and a lower activity than the stem bark extract at all the tested concentrations. A comparison of the percentages of inhibition of the extracts and that of the positive control compound rutin indicated a radical scavenging activity comparable to that of the control, as shown in Figure 2. At a concentration of $100 \mu \mathrm{g} / \mathrm{ml}$, the ethanol extracts of stem bark, 
leaves and stem wood showed a percentage of inhibition of the DPPH radical of $94.75 \% \pm 0.27 ; 57.27 \% \pm 4.20$ and $42.83 \% \pm$ 2.43 , respectively. Because the stem wood extract showed less activity, it was not fractionated.

The hexane, chloroform, ethyl acetate and hydromethanol fractions resulting from the liquid-liquid partitioning of the ethanol extracts of stem bark and leaves were subjected to quantitative antioxidant assays.

The hexane fractions of the ethanol extracts of stem bark and leaves presented a low percentage of inhibition of DPPH radical, proving to be poor in antioxidant compounds. The ethyl acetate fractions of stem bark and leaves at the concentration of $100 \mu \mathrm{g} / \mathrm{ml}$ reduced the DPPH by $93.49 \% \pm 2.85$ and $92.33 \% \pm$ 3.12 , respectively, indicating that these fractions were the most active, as shown in Figure 3.

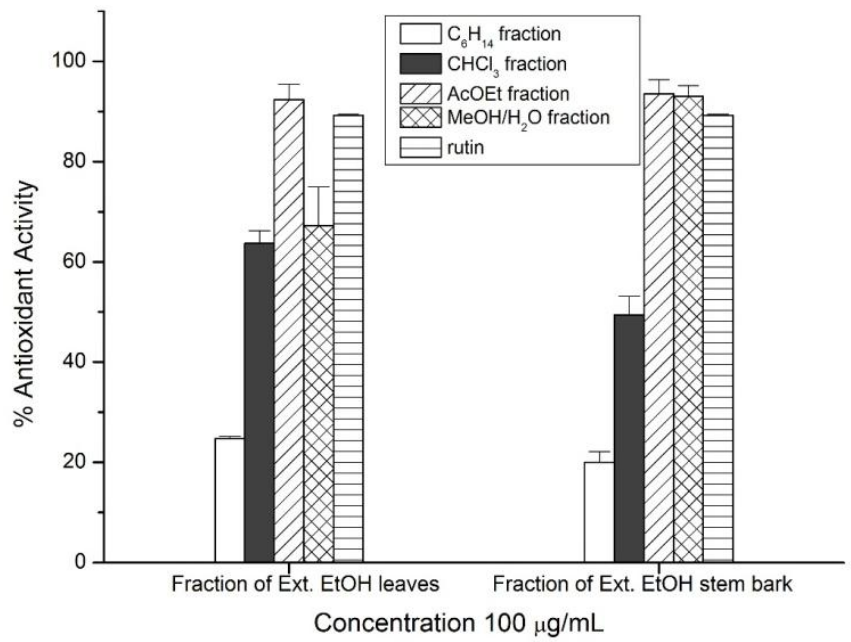

Fig. 3: Antioxidant activity of the fractions of ethanol extracts of leaves and stem bark of $X$. americana

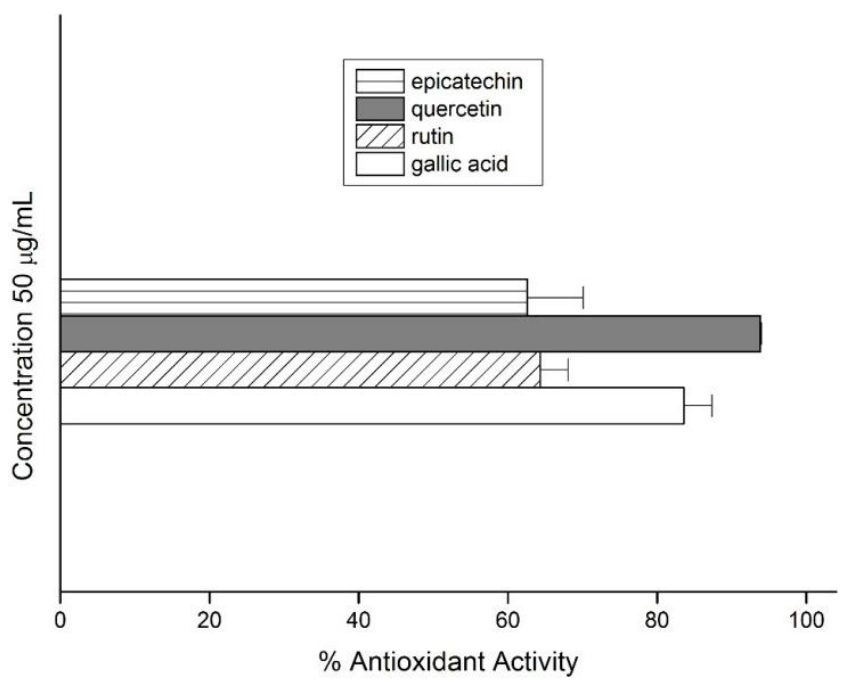

Fig. 4: Antioxidant activity of the compounds isolated from $X$. americana and controls at the concentration of $50 \mu \mathrm{g} / \mathrm{mL}$

The flavonoids epicatechin (1) from stem bark and quercetin (2) from leaves were isolated from the ethyl acetate fractions. At the concentration of $50 \mu \mathrm{g} / \mathrm{ml}$, the isolated compounds epicatechin (1) and quercetin (2) and the positive controls gallic acid and rutin presented a percentage of DPPH inhibition of $62.62 \% \pm 2.5 ; 93.84 \% \pm 0.13 ; 83.59 \% \pm 3.7$ and $64.4 \% \pm 3.73$, respectively, as shown in Figure 4 .

Figure 5 shows the kinetic behavior of the reaction of DPPH with each extract or control, at the concentration of 100 $\mu \mathrm{g} / \mathrm{ml}$, based on the dose-response curve of the decrease in percentage of remaining DPPH $\left(\mathrm{DPPH}_{\mathrm{REM}}\right)$ as a function of time (min). As can be seen, almost all the samples reduced the initial concentration of DPPH before of five minute of analysis, a behavior comparable to that of the positive control (rutin), and can therefore be classified as an antioxidant of rapid kinetics ( 0 to 5 min) (Sousa et al., 2007). Only the samples of ethanol extract and hydromethanol fraction of the leaves were considered antioxidants of slow kinetics (after $30 \mathrm{~min}$ ).

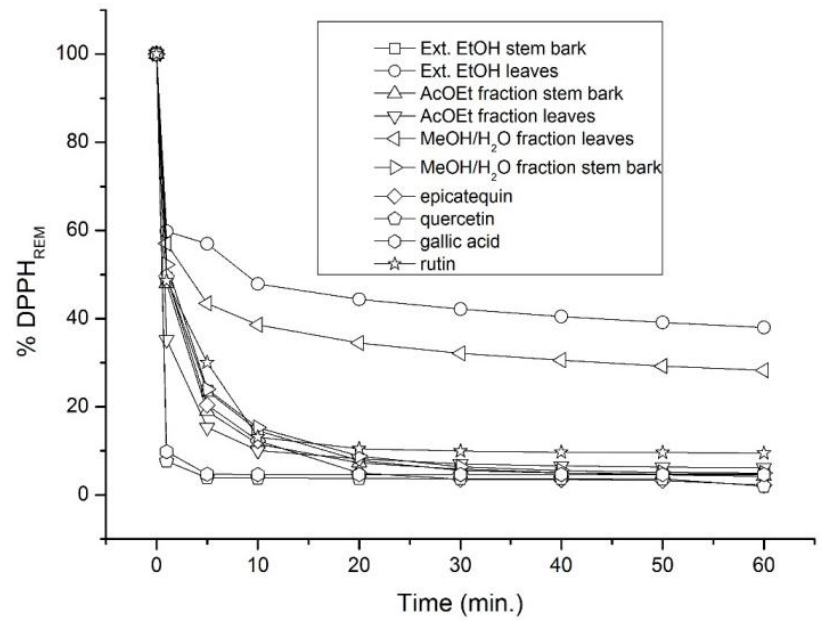

Fig. 5: $\% \mathrm{DPPH}_{\text {rem }}$ of the samples at the concentration of $100 \mu \mathrm{g} / \mathrm{ml}$.

The increasing order of speed of the scavenging action was found to be: rutin control $<$ epicatechin $<\mathrm{MeOH} / \mathrm{H} 2 \mathrm{O}$ fraction (stem bark) $<$ EtOAc fractions (leaves) $<$ EtOH extract (stem bark) $<$ EtOAc fractions (stem bark) $<$ gallic acid $<$ quercetin, as shown in Table 1 . The $\mathrm{EC}_{50}$ is a parameter widely used to determine the antioxidant power of extracts or substances, and it can be stated that the lower the $\mathrm{EC}_{50}$ value the higher the free radical scavenging power (Sanchez-Moreno et al., 1998).

The EC50 values of the extracts, fractions and compounds of $\mathrm{X}$. americana were calculated, and the results indicate that the values of the ethyl acetate fractions of stem bark $(29.62 \mu \mathrm{g} / \mathrm{mL} \pm 3.00)$ and of leaves $(33.03 \mu \mathrm{g} / \mathrm{ml} \pm 2.66)$ of $\mathrm{X}$. americana are lower than the standard compound, the rutin $(47.08$ $\mu \mathrm{g} / \mathrm{ml} \pm 4.65)$ and higher than gallic acid $(24.90 \mu \mathrm{g} / \mathrm{ml} \pm 0.04)$. The high radical scavenging activity of these fractions may be justified by the presence of epicatechin (1) $(34.64 \mu \mathrm{g} / \mathrm{ml} \pm 3.00)$ and quercetin (2) $(16.40 \mu \mathrm{g} / \mathrm{ml} \pm 1.30)$.

Even though the extracts present compounds such as quercetin (leaves) and epicatechin (stem bark), it is not possible to infer unequivocally that these are the only compounds responsible 
for the observed action, since the raw extract of stem bark and the EtOAc fraction of leaves show a result similar to that of the epicatechin compound.

Table 1: Total phenol (TP) content and antioxidant activity $\left(\mathrm{EC}_{50}\right)$ of the EtOH extracts and fractions of Ximenia americana.

\begin{tabular}{|c|c|c|}
\hline Samples & $\begin{array}{c}\mathrm{EC}_{50} \pm \mathrm{SD} \\
(\mu \mathrm{g} / \mathrm{mL})\end{array}$ & $\begin{array}{c}\text { TP (mg of } \\
\text { GAE/g of EtOH } \\
\text { extract } \pm \text { SD) }\end{array}$ \\
\hline EtOH extract of stem bark & $32.68 \pm 0.18$ & $678.66 \pm 2.31$ \\
\hline EtOH extract of stem wood & $101.72 \pm 10.33$ & $447.47 \pm 4.87$ \\
\hline EtOH extract of leaves & $68.30 \pm 5.10$ & $665.37 \pm 2.50$ \\
\hline $\mathrm{C}_{6} \mathrm{H}_{14}$ fraction (leaves) & $272.31 \pm 9.67$ & $153.29 \pm 9.23$ \\
\hline $\mathrm{CHCl}_{3}$ fraction (leaves) & $60.31 \pm 2.31$ & $449.76 \pm 7.90$ \\
\hline AcOEt fraction (leaves) & $33.03 \pm 2.66$ & $662.24 \pm 3.08$ \\
\hline $\mathrm{MeOH} / \mathrm{H}_{2} \mathrm{O}$ fraction (leaves) & $53.84 \pm 3.53$ & $625.37 \pm 8.01$ \\
\hline $\mathrm{C}_{6} \mathrm{H}_{14}$ fraction (stem bark) & NA & $90.25 \pm 2.38$ \\
\hline $\mathrm{CHCl}_{3}$ fraction (stem bark) & $84.24 \pm 3.00$ & $243.51 \pm 3.00$ \\
\hline AcOEt fraction (stem bark) & $29.62 \pm 2.91$ & $878.47 \pm 0.75$ \\
\hline $\mathrm{MeOH} / \mathrm{H}_{2} \mathrm{O}$ fraction (stem bark) & $33.65 \pm 5.07$ & $736.84 \pm 1.50$ \\
\hline Compound - epicatechin (stem bark) & $34.64 \pm 3.00$ & NT \\
\hline Compound - quercetin (leaves) & $16.40 \pm 1.30$ & NT \\
\hline
\end{tabular}

NA - Not active; NT - Not tested.

The determination of total phenols is an indirect method of evaluation of antioxidant activity, providing important information that can characterize natural products as sources of free radical scavenging substances (Roginsky and Lissi, 2005). Among the various methods developed for the quantification of phenolic compounds, the Folin-Ciocalteu reagent method has been widely used (Atoui et al., 2005).

The results of the analysis of total phenols represent the behavior found in the analysis of the antioxidant action. The ethanol extract of stem bark and the ethyl acetate, hydromethanol and chloroform fractions showed a total phenol content of 678.66; $878.47 ; 736.84$ and $243.51 \mathrm{mg}$ of EAG, respectively. On the other hand, the ethanol extract of leaves and the ethyl acetate, hydromethanol and chloroform fractions showed a total phenol content of 665.37; 662.24; 625.26 and $449.76 \mathrm{mg}$ of EAG, respectively, as indicated in Table 1 . From these results, it can be observed that the evaluated samples presented a high percentage of phenolic compounds.

The highest total phenolic content for ethanol extracts of stem bark and leaves were found in the ethyl acetate fraction. The chloroform fractions of both the stem bark and leaves presented a lower contents of total phenols, which is consistent with the lower antioxidant activity observed in the DPPH assay.

\section{CONCLUSION}

In this work, leaves and stem bark of Ximenia americana presented high radical scavenging activity by the DPPH photocolorimetric method and high total phenol content. The stem bark showed better results than the leaves. The quercetin compound isolated from the leaves had a better free radical scavenging activity compared to the positive controls gallic acid and rutin. This is the first report of the occurrence of epicatechin in this specie, as well of the DPPH radical scavenging activity and total phenolic content of ethanol extract $(\mathrm{EtOH})$ and fractions of the stem bark of $X$. americana.

\section{ACKNOWLEDGEMENTS}

The authors acknowledge financial support from $\mathrm{CNPq}$ and CAPES. They are also grateful to Dr. M. E. Alencar (Herbário Graziela Barroso, UFPI) for providing the identification of botanical material

\section{REFERENCES}

Argolo, ACC, Sant'ana, AEG, Pletsch, M, Coelho, LCBB. Antioxidant activity of leaf extracts from Bauhinia monandra. Bioresour Technol, 2004; 95:229-233.

Atoui, AK, Mansouri, A, Boskou, G, Kefalas, P. Tea and herbal infusions: Their antioxidant activity and phenolic profile. J Agric Food Chem, 2005; 89:27-36.

Braga, R. 1960. Plantas do Nordeste, Especialmente do Ceará. Natal, Ed. Universitária.

Costa DA, Chaves MH., Silva, WCS, Costa, CLS. Constituintes químicos, fenóis totais e atividade antioxidante de Sterculia striata St. Hil. et Naudin. Acta Amaz, 2010; 40:207-212.

Da Silva, KM, Chaves, TP, Santos, RL, Brandão, DO, Fernandes, FHA, Ramos-Junior, FJL, Dos Santos, VL, Felismino, DC, Medeiros, ACD. Modulation of the erythromycin resistance in Staphylococcus aureus by ethanolic extracts of Ximenia americana $\mathrm{L}$ and Schinopsis brasiliensis Engl. BLACPMA, 2015; 14:92-98.

Fatope, MO, Adoum, OA, Takeda, Y. C18 Acetylenic Fatty Acids of Ximenia americana with Potential Pesticidal Activity. J Agric Food Chem, 2000; 48:1872-1874.

Ferreira, ELF, Mascarenhas, TS, Oliveira, JPC, Chaves, MH, Araújo, BQ, Cavalheiro, AJ. Phytochemical investigation and antioxidant activity of extracts of Lecythis pisonis Camb. J. Med. Plants Res, 2014; 8:353-360

Fu, L, Chen, H, Dong, P, Zhang, X, Zhang, M. Effects of ultrasonic treatment on the physicochemical properties and DPPH radical scavenging activity of polysaccharides from mushroom Inonotus obliquus. J Food Sci, 2010; 75:322-327.

Geyid, A, Abebe, D, Debella, A, Makonnen, Z, Aberra, F, Teka, F, Kebede, T, Urga, K, Yersaw, K, Biza, T, Mariam, BH, Guta, M. Screening of some medicinal plants of Ethiopia for their anti-microbial properties and chemical profiles. J Ethnopharmacol, 2005; 97:421-427.

James, DB, Owolabi, AO, Ibiyeye, H, Magaji, J, Ikugiyi, YA. Assessment of the hepatic effects, hematological effect and some phytochemical constituents of Ximenia americana (Leaves, stem and root) extracts. Afr J Biotechnol, 2008; 7:4274-4278.

Kawo, AH, Suleiman, ZA, Yusha'u, M. Studies on the antibacterial activity and chemical constituents of Khaya senegalensis and Ximenia americana leaf extracts. Afr J Microbiol Res, 2011; 5:4562-4568.

Koné, WM, Atindehou, KK, Terreaux, C, Hostettmann, K, Traoré, D, Dosso, M. Traditional medicine in North Côte-d'Ivoire: screening of 50 medicinal plants for antibacterial activity. J Ethnopharmacol, 2004; 93:43-49.

Le, NHT, Malterud, KE, Diallo, D, Paulsen, BS, Nergård, CS, Wangensteen, H. Bioactive polyphenols in Ximenia americana and the traditional use among Malian healers. J Ethnopharmacol, 2012; 139:858862.

Lodyato, VI, Yurkova, IL, Sorokin, VL, Shadyro, OI, Kisel, AM. Novel (3,5-di-tert-butyl-2-hydroxy-phenylcarbamoyl)-alkanoic acids as potent antioxidants. Bioorg. Med. Chem. Lett, 2004; 14:4253-4256.

Lopes, LS, Marques, RB, Fernandes, HB, Pereira, SS, Ayres, MCC, Chaves, MH, Almeida, FRC. Mechanisms of the antinociceptive action of (-) Epicatechin obtained from the hydroalcoholic fraction of Combretum leprosum Mart \& Eic in rodents. J Biomed Sci, 2012; 19:1-6.

Maikai, VA, Kobo, PI, Maikai, BV. Antioxidant properties of Ximenia americana. Afr J Biotechnol, 2010; 9: 7744-7746.

Mevy, JP, Bessiere, JM, Greff, S, Zombre, G, Viano, J. Composition of the volatile oil from the leaves of Ximenia americana $\mathrm{L}$. Biochem Syst Ecol, 2006; 34:549-553.

Omer, MEFA, Elnima, EI. Antimocrobial Activity of Ximenia americana. Fitoterapia, 2003; 74:122-126. 
Pott, A, Pott, VJ. 1994. Plantas do Pantanal; Empresa Brasileira de Pesquisa Agropecuária, Centro de Pesquisa Agropecuária do Pantanal, Corumbá - Mato Grosso, Brazil.

Sánchez-Moreno, C, Larrauri, JA, Saura-Calixto. A procedure to measure the antiradical efficiency of polyphenols. J Sci Food Agric, 1998; 76:270-276.

Sharma, S, Kori, S, Parmar, A. Surfactant mediated extraction of total phenolic contents (TPC) and antioxidants from fruits juices. Food Chem, 2015; 185:284-288.

Soler-Rivas, C, Espín, JC, Wichers, HJ. An easy and fast test to compare total free radical scavenger capacity of food stuff., Phytochem Anal, 2000; 11:1-9.

Soro TY, Traore, F, Datte, JY, Nene-Bi, AS. Antipyretic activity of aqueous extract from Ximenia americana. Phytotherapie, 2009; 7:297-303.

Sousa, CMM., Silva, HR, Vieira-Júnior, GM, Ayres, MCC, Da Costa, CLS, Araújo, DS, Cavalcante, LCD, Barros, EDS, Araújo, PBM, Brandão, MS, Chaves, MH. Fenóis totais e atividade antioxidante de cinco plantas medicinais. Quim Nova, 2007; 30:351-355.

Roginsky, V, Lissi, EA. Review of methods to determine chainbreaking antioxidant activity in food. Food Chem, 2005; 92:235-234.

Voss, C, Eyol, E, Frank, M, Von Der Lieth, CW, Berger, MR. Identification and characterization of riproximin, a new type II ribosomeinactivating protein with antineoplastic activity from Ximenia americana, J FASEB, 2006; 20:334-345.
Wei, XH, Yang, SJ, Liang, N, Hu, DY, Jin, LH, Xue, W, Yang S. Chemical Constituents of Caesalpinia decapetala (Roth) Alston. Molecules, 2013; 18:1325-1336.

Yin, DD, Yuan, RY, Wu, Q, Li, SS, Shao, S, Xu, YJ, Hao, WH, Wang, LS. Assessment of flavonoids and volatile compounds in tea infusions of water lily flowers and their antioxidant activities. Food Chem, $2015 ; 187: 20-28$.

Zhang, D, Hamauzu, Y. Phenolics, ascorbic acid, carotenoids and antioxidant activity of broccoli and their changes during conventional and microwave cooking. Food Chem, 2004; 88:503-509.

\section{How to cite this article:}

Uchôa VT, Sousa CMM, Carvalho AA, Sant'Ana AEG, Chaves MH. Free radical scavenging ability of Ximenia americana L. stem bark and leaf extracts. J App Pharm Sci, 2016; 6 (02): 091-096. 